\title{
Relationship between glycemic control and serum uric acid level in acute myocardial infarction
}

\author{
Sadananjali ${ }^{1 *}$, M anasa $D R^{2}$
}

${ }^{1}$ Assistant Professor, Department of Biochemistry, KBN Institute of M edical Sciences, Kalaburgi, Karnataka, INDIA. 2Tutor, Department of Biochemistry, Belagavi Institute of M edical Sciences, Belagavi, Karnataka, INDIA.

Email: hukkeri.anjali@gmail.com

$\underline{\text { Abstract }}$

Background: Recent data have suggested that serum uric acid (SUA) level is positively associated with the development of type 2 diabetes (T2DM). We also know that diabetes is also independent risk factor for cardiovascular diseases. Objectives: To study the relationship between glycemic control and serum uric acid level in Acute MI cases. Material and Methods: A prospective cross sectional study on 100 AMI cases done at tertiary care intensive unit. They were divided into two groups, group I with only AMI cases and group II with AMI cases having poor glycemic control. Data was analyzed using SPSS and mean, SD and p value was calculated. Results: Out of 100 cases $62 \%$ cases were males and $38 \%$ cases were female in this study. Mean age of study was $53.7 \pm 15.7$ years. The mean serum uric acid level in group I was $5.26 \mathrm{mg} / \mathrm{dl}$ and in group II was $5.17 \mathrm{mg} / \mathrm{dl}$. There was no any significant association $(\mathrm{p}>0.05)$ between serum uric acid levels in both the groups. The mean blood glucose level in group I was $113.4 \mathrm{mg} / \mathrm{dl}$ and in group II it was $283.7 \mathrm{mg} / \mathrm{dl}$. The glucose level was significantly higher $(\mathrm{p}<0.05)$ in group II when compared with group I. The mean HbA1c level in group I was $5.12 \%$ while in group II it was $8.79 \%$. There was significantly higher $(\mathrm{p}<0.05)$ HbA1c seen in group II. Conclusions: More research in this regards should be done.

Key Word: Serum Uric Acid, Hyperglycemia, Myocardial Infarction

*Address for Correspondence:

Dr. Sadananjali, Assistant Professor, Department of Biochemistry, KBN Institute of Medical Sciences, Kalaburgi, Karnataka, INDIA.

Email: hukkeri.anjali@gmail.com

Received Date: 28/01/2019 Revised Date: 11/03/2019 Accepted Date: 07/05/2019

DOI: https://doi.org/10.26611/10021021

\begin{tabular}{|l|l|}
\hline \multicolumn{2}{|c|}{ Access this article online } \\
\hline Quick Response Code: & Website: \\
& www.medpulse.in \\
\cline { 2 - 2 } & \\
\hline
\end{tabular}

\section{INTRODUCTION}

Acute myocardial infarction (AMI) has already established itself as a major risk to health both in developed and developing nations. ${ }^{1,2}$ Recent studies concludes that concentrations of serum uric acid can be a cheap and easy-to-obtain indicator of cardiovascular risk. ${ }^{3,4}$ Serum uric acid levels are increased in patients with ischemic heart disease. Levels also increase with age, obesity, high alcohol consumption, combined hyperlipidemias, diabetes mellitus and hypertension. These cluster of abnormalities in turn significantly increase the risk of atherosclerotic vascular diseases like myocardial infarction (MI) and stroke. ${ }^{5}$ Diabetes mellitus (DM) can be described as a group of disorders of carbohydrate metabolism in which glucose is produced in large amounts, leading to hyperglycemia. ${ }^{6}$ Diabetes increases the risk of cardiovascular disease and stroke, about $50 \%$ of people with diabetes die of cardiovascular disease. $^{7}$ Hyperglycemia acts as a multiplier of cardiovascular risk and is implicated in vascular damage and cardiac myocyte death through different molecular mechanisms. ${ }^{8}$ Little is known on the association between uric acid and stroke risk: an association was found between uric acid and stroke risk in diabetics ${ }^{9}$ and between uric acid and fatal stroke in the general population..$^{10}$ Also there are less studies on this topic so we conducted this to study the relationship between 
glycemic control and serum uric acid level in Acute MI cases.

\section{MATERIAL AND METHODS}

This was a prospective cross sectional study conducted on AMI cases at ESIC Medical College, Kalaburgi , Karnataka, who were admitted in intensive care unit of this hospital. This study was conducted for a period of 1 year. Inclusion criteria: All the cases presenting with AMI at intensive care unit, aged above 20 years, AMI with diabetes taken as control group, those who have given consent for this study. Exclusion criteria: All those without AMI, with known systemic disorder other than cardiovascular and diabetes, all those who did not give consent. Cases were divided into two groups namely group I (50) with AMI alone and group II (50) those with AMI and poor glycemic control $(\geq 8 \% \mathrm{HbA} 1 \mathrm{c})$. The diabetic patients were classified as per HbAlc level. ${ }^{11}$ Informed consent was taken from patients or from their families. Detailed history was taken with the help of preformed proforma. For sample collection, venous blood taken after overnight fasting, serum separated. Simultaneously, blood samples were collected in ethylenediaminetetraacetic acid anticoagulation tubes for HbA1c estimation. HbA1c was estimated by Turbidimetric inhibition immunoassay method ${ }^{12}$ and Serum Uric acid by Uricase Method. ${ }^{13}$ study was approved by the ethics committee. Data was analyzed using SPSS version 20 and percentage mean, SD, p value was calculated. $\mathrm{p}<0.05$ taken as significant finding.

\section{RESULTS}

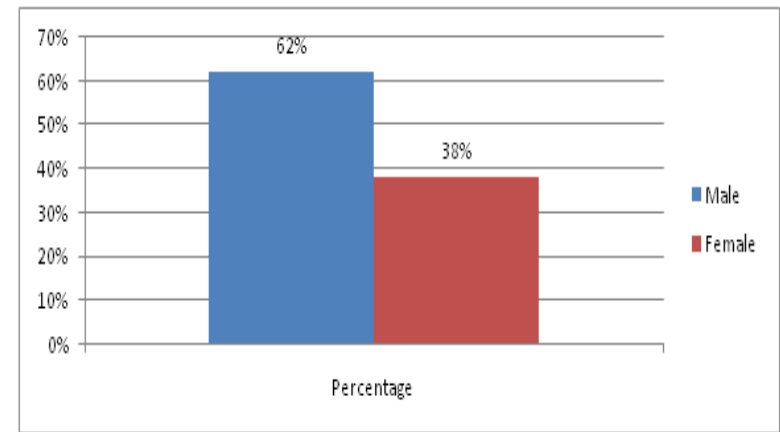

Diagram 1: Gender wise distribution of cases

$62 \%$ cases were males and $38 \%$ cases were female in this study. Mean age of study was $53.7 \pm 15.7$ years.

Table 1: Distribution of cases as per parameters

\begin{tabular}{cccc}
\hline Parameter & Group I & Group II & p value \\
\hline Serum uric acid $\mathbf{~ m g / ~ d l ~}$ & $5.26(1.32-9.43)$ & $5.17(1.78-10.23)$ & $>0.05$ \\
Blood glucose level mg/dl & $113.4(80-147)$ & $283.7(93-461)$ & $<0.05$ \\
HbAlc \% & $5.12(4.3-6.2)$ & $8.79(7.3-11.8)$ & $<0.05$ \\
\hline
\end{tabular}

The mean value of serum uric acid in group I was found to be 5.26 (1.32-9.43)mg/dl, in group II it was 5.17(1.78$10.23) \mathrm{mg} / \mathrm{dl}$. In group I the mean blood glucose level was 113.4 (80-147) $\mathrm{mg} / \mathrm{dl}$ and in group II it was 283.7 (93-461) $\mathrm{mg} / \mathrm{dl}$, in group I the means value of HbA1c \% was $5.12(4.3-6.2) \mathrm{mg} / \mathrm{dl}$ and in group II it was found to be 8.79(7.3$11.8) \mathrm{mg} / \mathrm{dl}$.

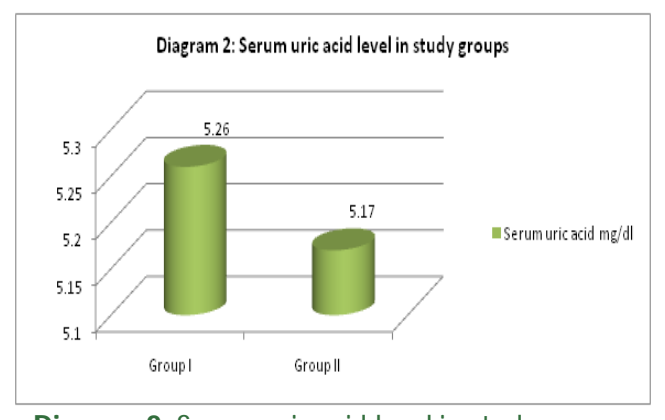

Diagram 2: Serum uric acid level in study groups

The mean serum uric acid level in group I was $5.26 \mathrm{mg} / \mathrm{dl}$ and in group II was $5.17 \mathrm{mg} / \mathrm{dl}$. There was no any significant association $(p>0.05)$ between serum uric acid levels in both the groups. 


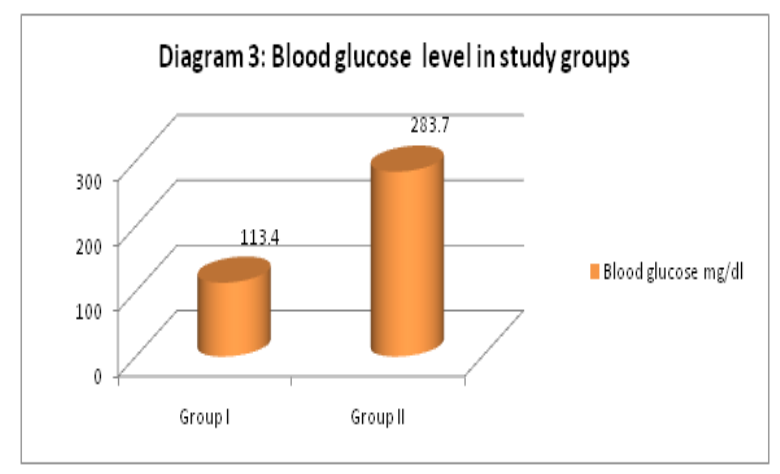

Diagram 3: Blood glucose level in study groups

The mean blood glucose level in group I was $113.4 \mathrm{mg} / \mathrm{dl}$ and in group II it was $283.7 \mathrm{mg} / \mathrm{dl}$. The glucose level was significantly higher $(\mathrm{p}<0.05)$ in group II when compared with group I.

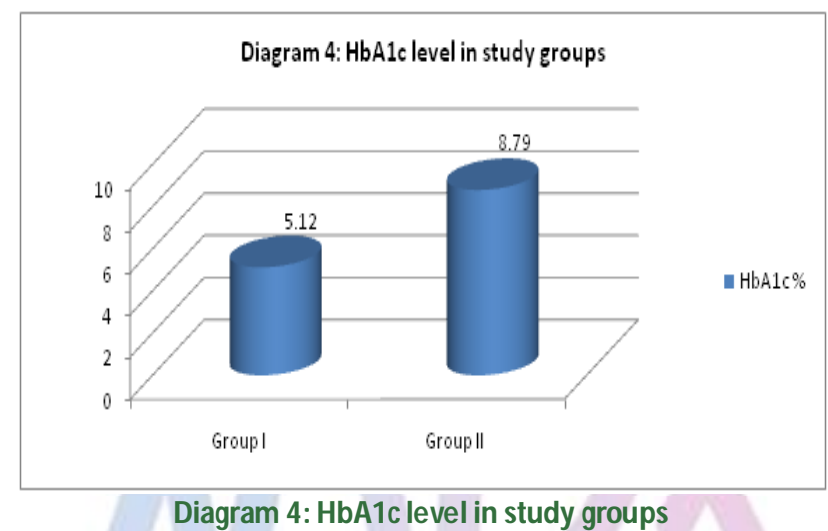

The mean HbA1c level in group I was $5.12 \%$ while in group II it was $8.79 \%$. There was significantly higher $(\mathrm{p}<0.05)$ HbAlc seen in group II.

\section{DISCUSSION}

This a prospective cross sectional study done on 100 cases with AMI. In this study out of total 100 cases $62 \%$ cases were males and $38 \%$ cases were female. Mean age of study was $53.7 \pm 15.7$ years. This result was in accordance with Burki L et $a l^{14}$ in their study males formed $70 \%$ and females formed $30 \%$ of the study. The mean age of Burki L et $a l^{14}$ study was found to be $50.0 \pm 12.4$, this was similar with our study. While higher mean age of 61 yearsand 62.6 was seen with Forman JPet $a l^{15}$ and Hajizadeh $\mathrm{R}$ et $a l .{ }^{16}$ In our study we did not find any significance between serum uric acid and glycemic control in infarction cases. Cirakli ZL et $a l^{17}$ and Biswas $\mathrm{K}$ et $a l^{18}$ also concluded the same. However, unlike our study Quiñones Galvan A et $a l^{19}$ found significant association between uric acid and glycemic control in AMI cases. There was no any statistically significant association between the HbAlc level and the uric acid level in any of our study groups. Higher glucose was seen in AMI cases in $\mathrm{Lv}$ et $a l^{20} \mathrm{In}$ this study, we can say that the serum uric acid level on raise with increase in fasting plasma glucose in group I, but seems to be decreasing in group II. This was found to be similar with Cirakli ZL et $a l^{17}$ and Nan $\mathrm{H}$ et $a l^{21}$ studies. According to few studies it is said that hyperuricemia increases the risk of developing diabetes in patients with hypertension. ${ }^{21}$ It is still not clear about role of uric acid and cardiovascular risk. Sluijset $a l{ }^{22}$ concluded that uric acid-lowering drugs may not be helpful in decreasing the risk of developing diabetes.

\section{CONCLUSION}

This study was a observational cross sectional study, so we cant generalize findings. A randomized control trial would have been better with larger sample size. There was significant association between blood glucose and HbA1c and AMI in two groups, but there was no significant association between serum uric acid and AMI in two groups in our study, further research is advisable.

\section{REFERENCES}

1. Yusuf S1, Hawken S, Ounpuu S, Dans T, Avezum A, Lanas F, et al. Effect of potentially modifiable risk factors associated with myocardial infarction in 52 countries (the interheart study): Case-control study. Lancet. 2004; 364(9438):937-52. 
2. Gagliardi A, Miname M, Santos R: Uric acid: A marker of increased cardiovascular risk. Atherosclerosis 2009, 202:11-17.

3. Meisinger C, Koenig W, Baumert J, Döring A: Uric acid levels are associated with all-cause and cardiovascular disease mortality independent of systemic inflammation in men from the general population: The Monica/Kora Cohort Study. ArteriosclerThrombVascBiol 2008, 28:1186-1192.

4. Shipley M, Black CM, Denton CP. Compston J, O'Gradaigh D. Rheumatology and bone disease. In: Kumar P, Clark M, editors. Clinical medicine. 6th ed. London: WB Saunders 2005: 529-603.

5. Masharani U. Diabetes mellitus and hypoglycemia. In: Tierney LM. McPhee SJ. Papadakis MA, editors. Current medical diagnosis and treatment. 45th ed. New York: McGraw-Hill 2006: 1194-239.

6. Krleza JL. Can glycated albumin assist in management of diabetes mellitus? BiochemiaMedica 2014; 24: S47-S52.

7. Morrish NJ, Wang SL, Stevens LK, Fuller JH, Keen H: Mortality and causes of death in the WHO Multinational Study of Vascular Disease in Diabetes. Diabetologia 2001, 44(Suppl 2):S14-S21.

8. Rahman $\mathrm{S}$, Rahman T, Ismail AA, Rashid AR. Diabetes ObesMetab. 2007 Nov; 9(6):767-80.

9. Lehto S, Niskanen L, Ronnemaa T, Laakso M. Serum uric acid is a strong predictor of stroke in patients with non-insulin-dependent diabetes mellitus. Stroke. 1998; 29: 635- 639.

10. Mazza A, Pessina AC, Pavei A, Scarpa R, Tikh+onoff V, Casiglia E. Predictors of stroke mortality in elderly people from the general population. The Cardiovascular Study in the Elderly. Eur J Epidemiol. 2001; 17:10971104.

11. Standards of medical care in diabetes--2015: summary of revisions. Diabetes Care 2015; 38 Suppl: S4.

12. Little RR, Wiedmeyer HM, England JD, Wilke AL, Rohlfing CL, Wians $\mathrm{FH}$, et al. Interlaboratory standardization of measurements of glycohemoglobins. Clin Chem. 1992;38:2472-2478

13. Trivedi R, Berta E and Rebar L. Enzymatic Uric acid determination at $500 \mathrm{~nm}$ by Trinder method. Clin. Chem 1976; $22: 1223$.

14. Burki L, Akram J, Mehmood A, Burki F. Serum Uric Acid Level in Hypertensive Patients with Acute Myocardial Infarction. Annals vol 19, issue 3, jul.-sep. 2013 Pp 243-248.

15. Forman JP,Choi H, Curhan GC. Plasma Uric Acid Level and Risk for Incident Hypertension Among Men.J Am SocNephrol 18: 2007, 287-292.

16. Hajizadeh R, Ghaffari S, Salehi R, Mazani S, Aghavali S. Association of serum uric acid level and mortality with morbidity of patients with acute ST-elevation myocardial infarction. J CardiovascThorac Res 2016;8(2):56-60.

17. Cirakli ZL, Neijmann ST, Kural A, Isiksacan N, Gedikbasi A, Erdin S. Relationship between glycemic control and serum uric acid level in acute myocardial infarction.Int J Med Biochem 2018;1(1):11-4.

18. Biswas K, Halder S, Sarkar R, Roy K. A study on prognostic significanceof serum uric acid in acute myocardial infarction in atertiary care institute. Int J Res Med Sci 2016;4: 4557-62.

19. Quiñones Galvan A, Natali A, Baldi S, Frascerra S, Sanna G, Ciociaro D, et al. Effect of insulin on uric acid excretion in humans. Am J Physiol 1995; 268: E1-5.

20. Lv et al:: Association between serum free fatty acid levels and possible related factors in patients with type 2 diabetes mellitus and acute myocardial infarction. BMC Cardiovascular Disorders 2014 14:159

21. Nan H, Dong Y, Gao W, Tuomilehto J, Qiao Q. Diabetes associated with a low serum uric acid level in a general Chinese population. Diabetes Res ClinPract 2007; 76: 68-74.

22. Sluijs I, Holmes MV, van der Schouw YT, Beulens JW, Asselbergs FW, Huerta JM, et al. A Mendelian Randomization Study of Circulating Uric Acid and Type 2 Diabetes. Diabetes 2015; 64: 3028- 36.

$$
\begin{aligned}
& \text { Source of Support: None Declared } \\
& \text { Conflict of Interest: None Declared }
\end{aligned}
$$

